\title{
Characterization and antioxidant assay of yellow frangipani flower (Plumeria alba) extract
}

\author{
Ahmad Fathoni ${ }^{1 *}$, Tarso Rudiana ${ }^{1,2}$, Adawiah $^{1}$ \\ 'Program Studi Kimia, Fakultas Sains dan Teknologi, UIN Syarif Hidayatullah Jakarta, Jl. Ir. Djuanda No.95, Cempaka Putih, \\ Ciputat,Tangerang Selatan, Banten, 15412, Indonesia \\ ${ }^{2}$ Program Studi Kimia, Fakultas Sains dan Farmasi, Universitas Mathla'ul Anwar Banten Jalan Raya Labuan KM 23, Cikaliung \\ Saketi, Pandegalang Banten, 42273, Indonesia
}

Received: 25 February 2019; Accepted: 23 April 2019

\begin{abstract}
:
Yellow frangipani flowers (Plumeria alba) are plants that commonly found in the tropics, including Indonesia. Frangipani utilization has not optimum and research about it has not many conducted. This study aims to characterize and test the antioxidant activity of frangipani flower extract. The extraction conducted by maceration method using $n$-hexane, ethyl acetate, and methanol as solvents. Characterization includes phytochemicals assay (alkaloids, flavonoids, terpenoids, phenolic hydroquinone, tannin-polyphenols, and saponins), total phenolic assay, and total flavonoid assay. Antioxidant test using DPPH radical scavenging assay. The results of the characterization showed that frangipani flower extract positively contained alkaloid, flavonoids, tannins compounds in all solvent phases. Terpenoids are positive in $n$-hexane and ethyl acetate extract, while saponins are positive in methanol extract. The total phenolic content of n-hexane, ethyl acetate, and methanol extract were $3.6 \mathrm{mgGAE} / \mathrm{g} ; 27.74 \mathrm{mgGAE} / \mathrm{g}$; and 35.23 $\mathrm{mgGAE} / \mathrm{g}$. The total flavonoid content of $\mathrm{n}$-hexane, ethyl acetate, and methanol extract were respectively $0.8 \mathrm{mgQE} / \mathrm{g} ; 12.18 \mathrm{mgQE} / \mathrm{g} ; 19.9 \mathrm{mgQE} / \mathrm{g}$. The strongest antioxidant activity is possessed by ethyl extract, followed by methanol extract, and the last are $n$-hexane extract.
\end{abstract}

Keywords:

Antioxidant; frangipani flower; phytochemical; total phenolic; total flavonoid

\section{Introduction}

Indonesia has large biodiversity, it is known that $15.5 \%$ of the total flora in the world can be found in Indonesia. One of them is a species of plumeria, better known as frangipani flowers (bunga kamboja) (Widjaja et al. 2014).

Frangipani flowers originally from Central America and are currently spread in various countries with tropical and subtropical climates (Missouri Botanical Garden, 2019). Among the many frangipani flower species found in Indonesia are yellow frangipani flowers (Plumeria alba). In Indonesia, frangipani flowers identical to the cemetery, and most frangipani plants are used for ornamental plants and for completing traditional ceremonies. Only a small portion is used as traditional medicine ingredients, and food ingredients (AgroMedia, 2008).

\footnotetext{
* Corresponding author.

fathoni.ahmad@uinjkt.ac.id

doi: https://doi.org/10.2 4114/jpkim.vlli 1.13034
}

Guevara et al. (1996), have reported that the ethanol extract of the green leaves of Plumeria acuminate contains four compounds with antimutagenic activity. Rasool et al. (2008), have reported that the ethanol extract of Plumeria acutifolia Poir. (Apocynaceae) stem bark was showed the strong in vitro antimicrobial activity and did not show any toxic symptoms to the tested animal. Gupta et al. (2006), have reported that the methanol extract of Plumeria acuminate leaves contain steroids, flavonoids, tannins, alkaloids, and glycosides.

Frangipani flowers are still not widely explored to increase their economic value. Therefore, further research is needed on the content of frangipani flowers. In this study characterization and testing of anti-oxidant activity of yellow frangipani flower (Plumeria alba) extract was carried out.

\section{Materials and Methods}

The research was conducted at the Center for Integrated Laboratories (PLT) of UIN Syarif 
Hidayatullah Jakarta. Extraction has been done by maceration with solvent replacement every 24 hours for three times immersion. The solvents used in the maceration process are $\mathrm{n}$-hexane, ethyl acetate, and methanol 99\% (Merck). Maserate evaporation using a rotary evaporator (Laborota 4000 ) under vacuum at a temperature of $50^{\circ} \mathrm{C}$. UV-Vis spectrophotometry analysis carried out by Genesys IOS UV-Vis Spectrophotometer (Thermo Scientific). The research stage can be seen in Fig 1.

The characterization of frangipani flower extract includes the test of alkaloids, flavonoids, terpenoids, phenolic hydroquinone, tanninpolyphenols, saponins (Harborne, 1973), total phenolic content (Baba \& Malik, 2014; John et al. 2014; Sukandar et al. 2018), and total flavonoid content (Baba \& Malik, 2014; John et al. 2014), in addition, also tested antioxidant activity (Garcia et al. 2012; Sukandar et al. 2018).

The alkaloid assay test was carried out with 10 $\mathrm{mL}$ of sample inserted into the test tube. $10 \mathrm{~mL}$ of chloroform and ten drops of ammonia were added. The chloroform fraction was taken and 0.5 $\mathrm{mL}$ of $2 \% \mathrm{HCl}$ was added. The sample was vortexed and then five drops of Wagner reagent were added (positive if brown deposits were formed).

The flavonoid assay test was carried out with 2 $\mathrm{mL}$ of the sample in the test tube, added a little $\mathrm{Mg}$ powder and ten drops of concentrated $\mathrm{HCl}$. Flavonoids are known to be positive if they are foam and bright orange.

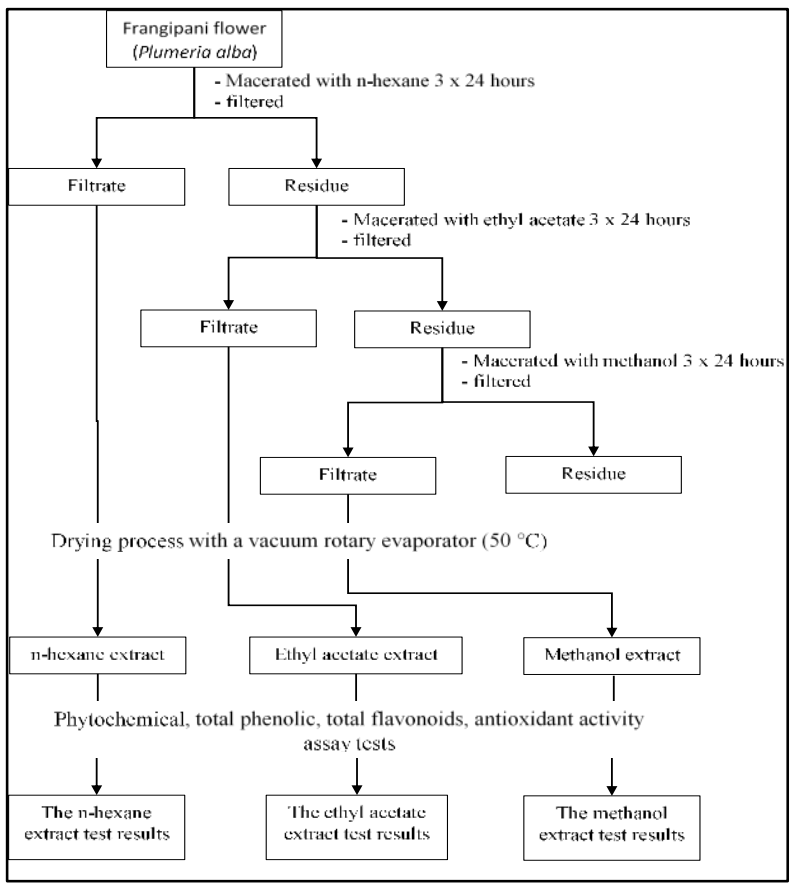

Fig 1. Research flow chart
Triterpenoid and steroid assay tests were carried out by reacting $2 \mathrm{~mL}$ samples with ten drops of Lieberman-Burchard reagent in a test tube. A positive sample contains triterpenoids if a brownish, red or purple ring is formed and is positive for steroids if it is green.

The phenolic hydroquinone assay test was carried out by reacting $2 \mathrm{~mL}$ of the sample with $2 \mathrm{~N} \mathrm{NaOH}$ in a test tube and shaking it. Positive samples contain quinones if they are red.

Tannin and polyphenol assay tests were carried out by reacting $2 \mathrm{~mL}$ of the sample with five drops of $1 \% \mathrm{FeCl}_{3}$ in a test tube and shaking. Positive samples contain tannin if they are greenish and positively contain polyphenols if they are bluish.

The saponin assay test was carried out with 1 gram of dried and fine plant samples and dissolved with $5 \mathrm{~mL}$ of distilled water in a test tube. The sample was heated in a water bath for 5 minutes. Continuing the filtration process to extract the filtrate. The sample is known to contain saponin by the appearance of foam after shaking positively and the foam is stable for \pm 10 minutes.

The total phenolic content assay was carried out by UV-Vis spectrophotometry method. Samples were prepared from $0.1 \mathrm{~g}$ of sample dissolved to $2.5 \mathrm{~mL}$ of distilled water and followed by adding $0.5 \mathrm{~mL}$ of Folin-Cioceltaeu reagent (1: 1) and incubated for 3 minutes. The next procedure is the addition of $2 \mathrm{~mL}$ of $20 \% \mathrm{NaCO}_{3}$ solution and heated with boiling Water Bath for 1 minute. After that, it is cooled in lce Bath, and its absorbance was measured at a wavelength of 750 $\mathrm{nm}$. The standard solution used is gallic acid solution. Total phenolic levels expressed in $\mathrm{mg}$ gallic acid equivalent / g sample ( $\mathrm{mgGAE} / \mathrm{g})$.

Total flavonoid content assay was carried out by UV-Vis spectrophotometry method. The sample used as much as $0.1 \mathrm{~g}$ of sample in $1 \mathrm{~mL}$ of solvent was added $3 \mathrm{~mL}$ of distilled water and $0.3 \mathrm{~mL}$ of $10 \% \mathrm{AlCl}_{3}$ solution. The resulting solution was centrifuged and incubated for 5 minutes and added aquadest to a volume of $10 \mathrm{~mL}$. Measured the absorbance at a wavelength of $430 \mathrm{~nm}$. The standard solution used is quercetin. Flavonoid content is expressed in $\mathrm{mg}$ quercetin equivalent / g sample (mgQE/g).

The antioxidant activity assay was carried out by the DPPH (1,1-diphenyl-2-picrylhydrazyl) method. Samples dissolved in methanol obtained samples with concentrations of $100,50,25$, and 10 ppm. Each sample is inserted into the test tube and added $2 \mathrm{~mL}$ DPPH $0.002 \%$. The sample 
solution was vortexed until homogeneous and incubated at $37^{\circ} \mathrm{C}$ for 30 minutes in a dark room. Measured the absorbance of the sample solution with a UV-Vis spectrophotometer at a wavelength of $520 \mathrm{~nm}$. The measurement conducted twice (Duplo). $2 \mathrm{~mL}$ methanol and $2 \mathrm{~mL}$ DPPH $0.002 \%$ were used as blank solutions. The ability of the sample as radical scavenging was obtained in the form of percent inhibition (Baba \& Malik, 2014; Latifah, 2015; Febrina et al. 2017).

$\%$ inhibition $=\frac{A_{\text {blank }}-A_{\text {sample }}}{A_{\text {blank }}} \times 100 \%$

The linear equation of antioxidant activity is generally expressed in:

$$
y=a x+c
$$

Description:

y: \% inhibition

$x$ : concentration

by entering the value $y=50$, the $1 C_{50}$ value of each extract was obtained.

Antioxidant activity was obtained from $\mathrm{IC}_{50}$ values (concentration of samples that capable of inhibiting $\mathrm{DPPH}$ up to $50 \%$ ). The $\mathrm{IC}_{50}$ value is obtained by making a curve between percent inhibition ( $y$-axis) and sample concentration ( $x$ axis). The ability of the sample as an antioxidant is described in $\mathrm{IC}_{50}$ values, which shows the ability of samples to inhibit free radicals by as much as $50 \%$. Table 1 shows the relationship of antioxidant activity with $\mathrm{IC}_{50}$ values.

Table 1

Relationship of $\mathrm{IC}_{50}$ values and antioxidant activity (Tristantini et al. 2016).

\begin{tabular}{cl}
\hline \multicolumn{1}{c}{$\mathrm{IC}_{50}$} & Antioxidant activity \\
\hline$<50 \mathrm{ppm}$ & Very strong \\
$50-100 \mathrm{ppm}$ & Strong \\
$100-150 \mathrm{ppm}$ & Moderate \\
$150-200$ & Weak \\
$<200 \mathrm{ppm}$ & Very weak \\
\hline
\end{tabular}

The equation calculates total phenolic and total flavonoids content (Abdelhady et al. 2011; Baba \& Malik, 2014; John et al. 2014):

Total Phenolic or Flavonoid $=\frac{X . V . d f}{g}$

Description

$X$ : $x$-axis value (ppm)

$V$ : volume of extract used (L)

$d f$ : dilution factor

g: weight of sample used.

\section{Results}

\section{Phytochemical}

Testing the content of alkaloids with Wagner reagents, positive samples containing alkaloids if brown deposits are produced. Wagner reagent reacts with $\mathrm{I}^{-}$ions from potassium iodide to produce $\mathrm{I}_{3}^{-}$ions which give a brown color. In the Wagner test, $\mathrm{K}^{+}$ions will form covalent coordination bonds with nitrogen in alkaloids forming the potassium-alkaloid complex that sediment. The reaction is as in Fig 2.

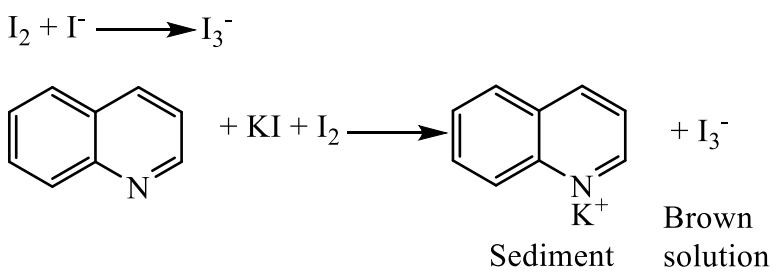

Fig 2. The reaction of an alkaloid test.

The flavonoid assay was carried out by the color test. The positive sample contains flavonoids if foam arises and is clear orange. The reaction is as in Fig 3.

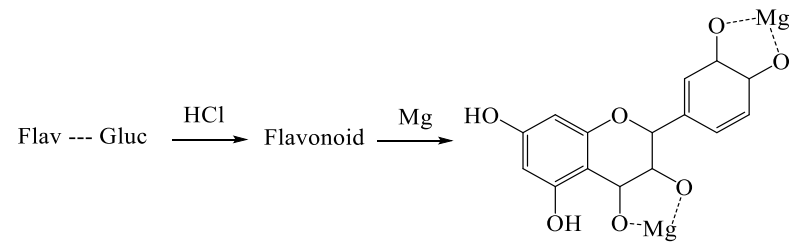

Fig 3. Flavonoid test reaction.

The triterpenoid/steroid assay test is based on triterpenoid/ steroid properties which can dehydrate by adding acids and forming salts which give some color reactions (Robinson, 1995). The reaction is as in Fig 4 .
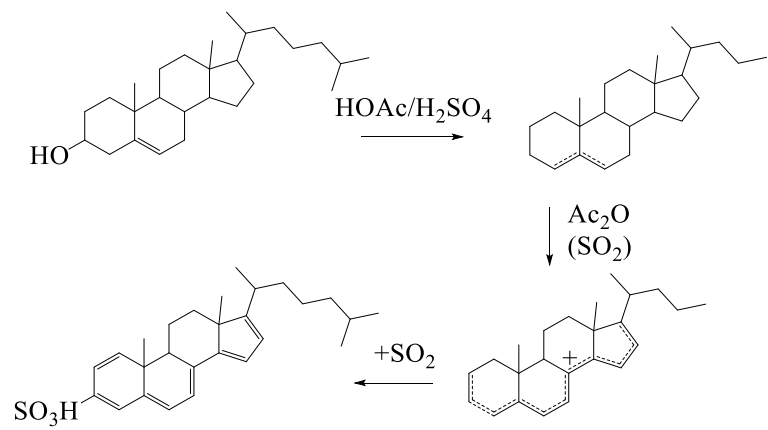

Fig 4. Triterpenoid/steroid test reaction.

Phenolic hydroquinone assay test was done by reacting the sample with $\mathrm{NaOH}$. A positive sample contains hydroquinone phenolic if it was formed in red, according to the reaction in Fig 5 (Chang, 2005). 
<smiles>O=[W]N=[N+]O</smiles>

Fig 5. The reaction of hydroquinone phenolic test.

Tannin/polyphenols assay is positively indicated by the formation of complex compounds with $\mathrm{Fe}^{3+}$. Samples positively contain tannin if they are greenish and positively contain polyphenols if they are bluish. The reaction is as in Fig 6.

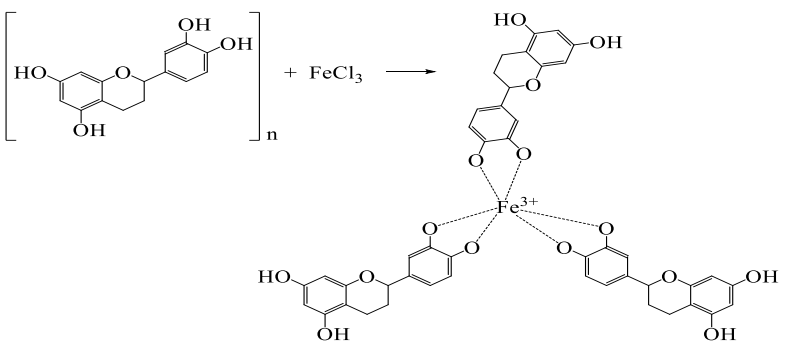

Fig 6. The reaction of tannin/polyphenol test.

The appearance of foam characterized saponin in the sample after shaking, and the foam was stable for \pm 10 minutes. The emergence of foam indicates the presence of hydrolyzed glycosides (Nugrahani et al. 2016). The reaction is as in Fig 7.

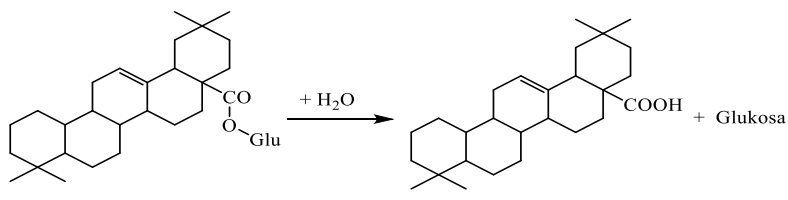

Fig 7. Saponin test reaction.

The results of the phytochemical assay on $n$ hexane, ethyl acetate, and methanol extract from frangipani flowers can be seen in Table 2.

Table 2

The results of the phytochemical assay

\begin{tabular}{lccc}
\hline & $\begin{array}{c}\text { n-hexane } \\
\text { extract }\end{array}$ & $\begin{array}{l}\text { Ethyl } \\
\text { acetate } \\
\text { extract }\end{array}$ & $\begin{array}{l}\text { Methanol } \\
\text { extract }\end{array}$ \\
\hline Alkaloid & + & + & + \\
Flavonoid & + & + & + \\
Terpenoid & + & + & - \\
Steroid & - & - & - \\
Hydroquinone & - & - & - \\
phenolic & - & + & + \\
Tannin & + & - & - \\
Poliphenol & - & - & + \\
Saponin & - & - & \\
\hline
\end{tabular}

\section{Total phenolic and total flavonoid content}

Total phenolic content was measured by UVVis spectrophotometry with gallic acid as a standard at a wavelength of $750 \mathrm{~nm}$. The calibration curve of gallic acid can be seen in Fig 8. The total flavonoid was measured by the same method with quercetin as a standard and measurement at a wavelength of $430 \mathrm{~nm}$. The calibration curve of quercetin can be seen in Fig 9.

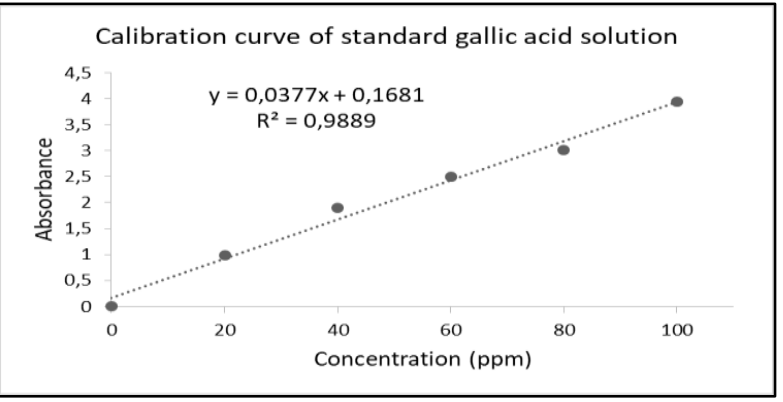

Fig 8. Gallic acid calibration curve.

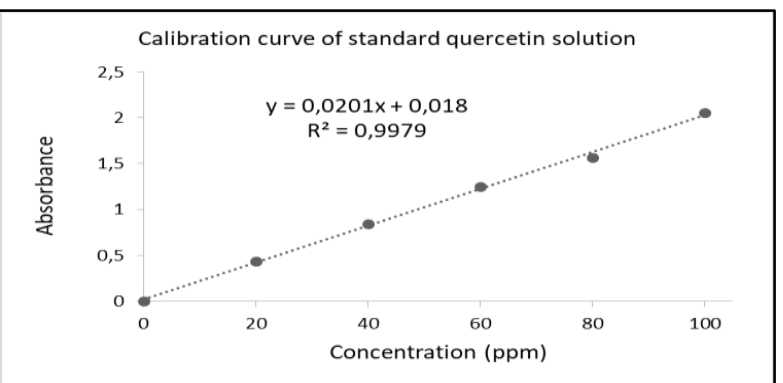

Fig 9. Quercetin calibration curve.

\section{Antioxidant activity}

The measurement of antioxidant activity is carried out using the DPPH radical scavenging assay to obtained the antioxidant activity curve in Fig 10. DPPH is a stable radical that can react with other radicals to form a stable compound or react with hydrogen atoms to form reduced DPPH (DPPH-H). The presence of antioxidant activity from the sample resulted in discoloration of DPPH in methanol which was originally dark purple to yellow (Baba \& Malik, 2014; Situmeang et al. 2016). The reactions that occur are as in Fig 11.

\section{Discussion}

Extraction was conducted gradually and the resulting samples were yellow frangipani flower extract phase n-hexane, ethyl acetate, and methanol. Each extract was characterized and tested for antioxidant activity. 


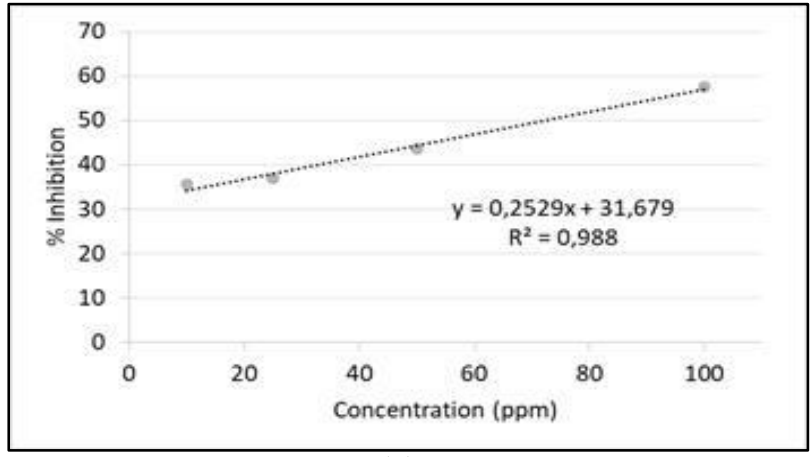

(a)

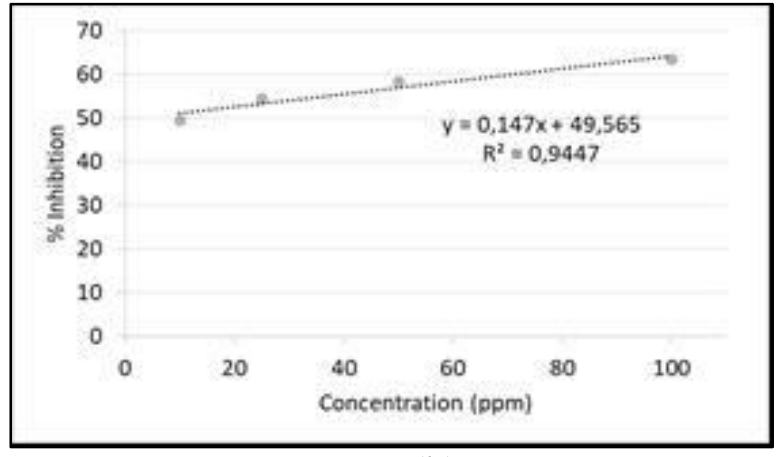

(b)

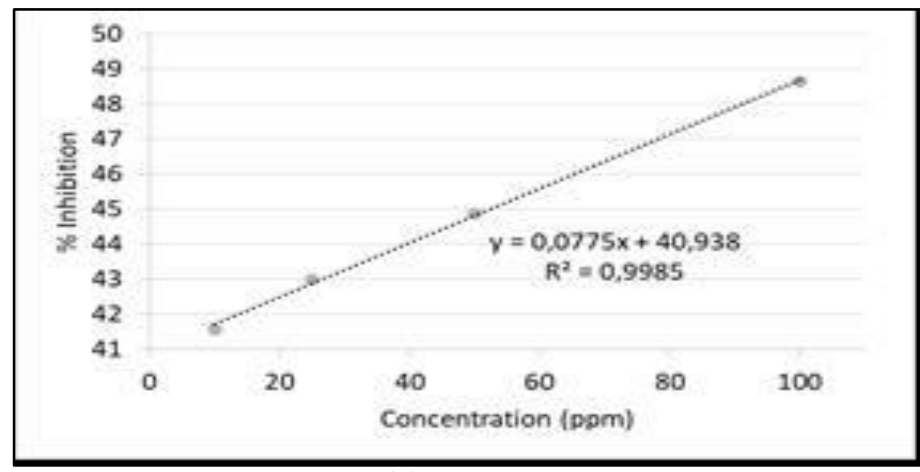

(c)

Fig 10. Antioxidant activity assay curve. (a) n-hexane extract; (b) ethyl acetate extract; (c) methanol extract.

The result of phytochemical assay shown that frangipani flower extract positively contains alkaloid, flavonoids, tannins in all solvent phases. Positive terpenoids in $\mathbf{n}$-hexane and ethyl acetate extract, while saponins are positive in methanol extract. This is consistent according to Plumeria acuminate leaves content reported by Gupta et al. (2006) and potentially to be further investigated about its biological activity.

The total phenolic and total flavonoid content calculated from the calibration curve. It was obtained two linear equation, the gallic acid had equation of $y=0.0377 x+0.1681$ and the quercetin had $y=0,0201 x+0,018$; with $y$ is the absorbance and $x$ is the concentration of the standard solution. The $\mathrm{R}^{2}$ value of gallic acid and quercetin respectively 0.9889 and 0,9979 (close to 1 ) indicates that the calibration curve can be used as a basis for calculating total phenolic and total flavonoid content.

The measurements of absorbance of samples and calculations obtained the total phenolic content in the extract of $n$-hexane, ethyl acetate, and methanol frangipani extract respectively were $3.6 \mathrm{mgGAE} / \mathrm{g} ; \quad 27.74 \mathrm{mgGAE} / \mathrm{g} ;$ and 35.23 $\mathrm{mgGAE} / \mathrm{g}$.

The total flavonoid content is expressed in units of $\mathrm{QE}$ (quercetin equivalent). Total flavonoid levels are calculated with the same equation with total phenolic content. So that the values of total flavonoids obtained for $n$-hexane, ethyl acetate, and methanol frangipani extract were respectively $0.8 \mathrm{mgQE} / \mathrm{g} ; 12.18 \mathrm{mgQE} / \mathrm{g} ; 19.9 \mathrm{mgQE} / \mathrm{g}$.

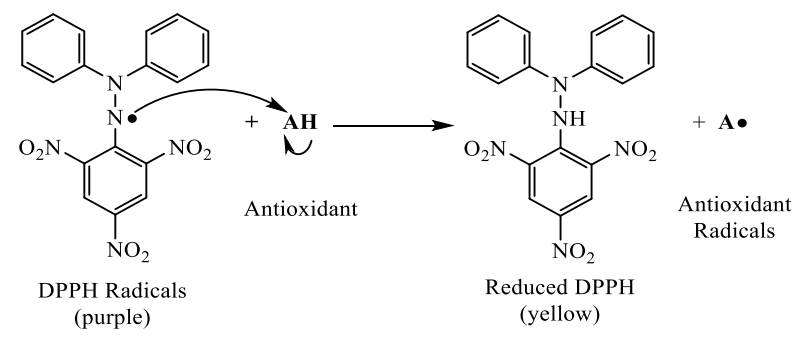

Fig 11. DPPH radical scavenging reaction reaction

The measurement results of total phenolic and total flavonoids content, it is known that in the frangipani flower extract, the total phenolic content and total flavonoids are more in the extraction with more polar solvents.

The sample concentrations used were 100, 50, 25 and $10 \mathrm{ppm}$. As a blank solution used is the DPPH standard solution. From the results of absorbance measurements and the calculation of the \% inhibition was obtained the curve of concentration with $\%$ inhibition.

The $\mathrm{IC}_{50}$ values are calculated based on the value of the linear equation produced. The $\mathrm{IC}_{50}$ value of $n$-hexane, ethyl acetate, and methanol 
extract of yellow frangipani flower extract was respectively $116.93 \mathrm{ppm}$ (moderate); $2.96 \mathrm{ppm}$ (very strong); $72.44 \mathrm{ppm}$ (strong). Frangipani flower extract with the strongest antioxidant activity was ethyl acetate extract, although the increase in $\%$ inhibition was not significant with increasing sample concentration. Antioxidant activity hypothetically correlated to antimutagenic activity of the green leaves of Plumeria acuminate corresponding to the research reported by Guevara et al. (1996).

\section{Conclusion}

Through phytochemical assay, it is known that frangipani flower extract positively contains alkaloid compounds, flavonoids, tannins in all solvent phases. Positive terpenoids in $\mathrm{n}$-hexane and ethyl acetate extract, while saponins are positive in methanol extract. The total phenolic content of frangipani $\mathrm{n}$-hexane, ethyl acetate, and methanol extract respectively were $3.6 \mathrm{mgGAE} / \mathrm{g}$; $27.74 \mathrm{mgGAE} / \mathrm{g}$; and $35.23 \mathrm{mgGAE} / \mathrm{g}$. The total flavonoid content of $\mathrm{n}$-hexane, ethyl acetate, and methanol extract respectively were $0.8 \mathrm{mgQE} / \mathrm{g}$; $12.18 \mathrm{mgQE} / \mathrm{g} ; 19.9 \mathrm{mgQE} / \mathrm{g}$. The strongest antioxidant activity is possessed by ethyl acetate extract, followed by methanol extract, and the lowest is $\mathrm{n}$-hexane extract.

\section{References}

Abdelhady, M. I. S., Motaal, A. A., \& Beerhues, L. (2011). Total phenolic content and antioxidant activity of standardized extracts from leaves and cell cultures of three Callistemon species. American Journal of Plant Sciences, 02(06), 847-850, doi: 10.4236/ajps.2011.26100.

AgroMedia (2008). Buku pintar tanaman obat. Jakarta: PT Agromedia Pustaka.

Baba, S. A., \& Malik, S. A. (2014). Determination of total phenolic and flavonoid content, antimicrobial and antioxidant activity of a root extract of Arisaema jacquemontii Blume. Journal of Taibah University for Science, 9(4), 449-454, doi: 10.1016/j.jtusci.2014.11.001.

Chang, R. (2005). Kimia dasar: Konsep-konsep inti Jilid l. Jakarta: Erlangga.

Febrina, L., Riris, 1. D., \& Silaban, S. (2017). Activity antibacterial to Escherichia coli and antioxsidant of extract water of leaf binara plant (Artemisia vulgaris L.) after blanching. Jurnal Pendidikan Kimia, 9(2), 311-317, doi: 10.24114/jpkim.v9i2.7621.

Garcia, E. J., Oldoni, T. L. C., Alencar, S. M. D., Reis, A., Loguercio, A. D., \& Grande, R. H. M. (2012). Antioxidant activity by DPPH assay of potential solutions to be applied on bleached teeth. Brazilian Dental Journal, 23(1), 22-27, doi: 10.1590/S0103-64402012000100004.

Guevara, A. P., Amor, E., \& Russell, G. (1996). Antimutagens from Plumeria acuminata Ait', Mutation Research/Environmental Mutagenesis and Related Subjects, 361(2-3), 67-72, doi: 10.1016/S0165-1161(96)90240-X.

Gupta, M., Mazumder, U. K., Gomathi, P., \& Selvan, V. T. (2006). Antiinflammatory evaluation of leaves of Plumeria acuminata. BMC Complementary and Alternative Medicine, 6(1), 1-6, doi: 10.1186/1472-6882-6-36.

Harborne, J. B. (1973). Phytochemical methods. Chapman and Hall Ltd. New York: Chapman and Hall, doi: 10.2307/4108146.

John, B. I. J. U., Sulaiman, C. T., George, S., \& Reddy, V. R. K. (2014). Total phenolics and flavonoids in selected medicinal plants from Kerala. International Journal of Pharmacy and Pharmaceutical Sciences, 6(1), 406-408.

Latifah (2015). Identifikasi golongan senyawa flavonoid dan uji aktivitas antioksidan pada ekstrak rimpang kencur Kaempferia galanga $L$. dengan metode DPPH (1,1-Difenil-2Pikrilhidrazil). Universitas Islam Negeri Maulana Malik Ibrahim Malang. Universitas Islam Negeri Maulana Malik Ibrahim Malang.

Missouri Botanical Garden (2019). Plumeria alba, Plant Finder. Missouri Botanical garden. Available at: http://www.missouribotanicalgarden.org/PlantFi nder/PlantFinderDetails.aspx?taxonid=276110\&is profile $=0 \&$ (Accessed: 24 February 2018).

Nugrahani, R., Andayani, Y., \& Hakim, A. (2016). Skrining fitokimia dari ekstrak buah buncis (Phaseolus vulgaris $\mathrm{L}$ ) dalam sediaan serbuk. Jurnal Penelitian Pendidikan IPA, 2(1), 96-103.

Jaheerunnisa, S., \& Chitta, S. K. (2008). Antimicrobial activities of Plumeria acutifolia. Journal of Medicinal Plants Research, 2(4), 077080.

Rasool, R., Kukal, S. S., \& Hira, G. S. (2008). Soil organic carbon and physical properties as affected by long-term application of FYM and inorganic fertilizers in maize-wheat system. Soil and Tillage Research, 101(1-2), 31-36, doi: 10.1016/j.still.2008.05.015.

Robinson, T. (1995). Kandungan organik tumbuhan tinggi. Bandung: ITB.

Situmeang, B., Nuraeni, W., lbrahim, A. M., \& Silaban, S. (2016). Analysis of secondary metabolite compounds from leaves extract kesambi (Schleichera oleosa) and antioxidant activity test. Jurnal Pendidikan Kimia, 8(3), 164- 
168.

Sukandar, D., Umedi, I. U., Nurbayti, S., Rudiana, T., \& Fathoni, A. (2018). Asam protokatekuat dari ekstrak etil asetat biji honje (Etlingera elatior) dan uji aktivitas antioksidannya. Jurnal Kimia Valensi, 4(1), 52-56.

Tristantini, D., Ismawati, A., Pradana, B. T., \& Jonathan, J. G. (2016). Pengujian aktivitas antioksidan menggunakan metode DPPH pada daun tanjung (Mimusops elengi L). Prosiding Seminar Nasional Teknik Kimia "Kejuangan", Gl-1-Gi-7.

Widjaja, E. A., Rahayuningsih, Y., Rahajoe, J. S., Ubaidillah, R., Maryanto, I., Walujo, E. B., \& Semiadi, G. (Eds.). (2014). Kekinian keanekaragaman hayati Indonesia, 2014. LIPI Press, doi: 10.1007/s13398-014-0173-7.2. 